\title{
Age Is Just a Number
}

\author{
By Susan Weinstock
}

C urrently, 10,000 baby boomers turn 65 every day, and this trend will continue until 2030. The US labor market is extremely tight, and labor force demographics are contributing to this squeeze. In fact, employers report that finding talent is currently among their top concerns.

AARP is working with employers to educate them on the value of experienced workers, and part of this effort is our Employer Pledge Program (EPP). The EPP is a nationwide group of employers that stand with AARP in affirming the value of experienced workers and are committed to developing diverse organizations. By signing the pledge, participating employers publicly affirm that they

- Believe in equal opportunity for all workers, regardless of age;

- Believe that workers ages 50 and older should have a level playing field in their ability to compete for and obtain jobs;

- Recognize the value of experienced workers; and
- Recruit across diverse age groups and consider all applicants on an equal basis.

As of this writing, almost 800 employers have signed the pledge, and we continue to seek out additional participants. Experienced workers can be the solution to lessen the impact of today's labor shortages, but unfortunately, persistent myths about this cohort too often become a barrier to retaining and hiring experienced workers. AARP is working with employers to dispel some of these myths so they can see the value in hiring and retaining these employees.

One terrible myth is that older workers are slow and can't keep up with their younger counterparts. In fact, productivity actually increases with age. Studies on older assembly line workers in Germany revealed that the ability to anticipate problems and either avoid them altogether or solve them on the fly meant that older workers' productivity, regardless of the physical demands of the job, didn't diminish with age, it increased.

Another myth is that older workers are not skilled in use of the latest technology - they don't use social media or know how to work their mobile devices. This myth overlooks the fact that baby boomers are the generation that invented the Internet, the personal computer, the Intel processor, and more. Everything that has made the current wave of technological innovation possible was invented by the boomers. Studies that have examined the performance of older tech workers have shown consistently that technical skills do not decline with age.

Yet another stubborn myth is that older workers are just coasting toward retirement and not interested in learning new things. AARP's research busts this myth as well: two essential elements of an ideal job for workers ages 45 to 64 include (a) the opportunity to learn something new (more than 80 percent) and (b) on-the-job training (more than 70 percent).

Another element of AARP's focus, besides busting myths about older workers, is to showcase their value. Our research shows that 65 percent of employees ages 55 and older in large companies are engaged, meaning that they speak positively about their 


\section{"Experienced workers can be the solution to lessen the impact of today's labor shortages, but unfortunately, persistent myths about this cohort too often become a barrier to retaining and hiring experienced workers."}

workplace, stay with their employer, and put forth their best effort, compared with 58-60 percent of employees under age 55 . Workers ages 55 and older are also the most motivated, in that they exert extra effort and contribute more than is normally required in their job, with 81 percent of workers ages 55 and older deemed motivated compared with 77 percent of workers ages 24-54. And engagement matters. Research shows that business units that score in the top quartile on employee engagement are 21 percent more productive, have 22 percent higher profitability, and experience 37 percent less absenteeism when compared with those in the bottom quartile.

Another great asset older workers bring to the table is applied skills, often called soft or baseline skills. These are skills garnered from years in the workforce, like professionalism, remaining calm under pressure, relationship building, emotional intelligence, and empathy.

Finally, older workers provide stability to the workforce due to their lower levels of unexpected turnover. Almost half of workers under 50 represent risk of unplanned turnover, since 39 percent said they would consider other offers and 10 percent were actively lookingwhereas only 29 percent of workers ages 50 and older pose the same risk. The costs of turnover are high; employers will need to spend the equivalent of six to nine months of an employee's salary in order to find and train his or her replacement. Having experienced workers in the mix can help reduce turnover costs in addition to keeping valuable institutional knowledge in house.

Age diversity in work teams is a key component of a successful workplace. When an employer develops and supports mixed-age teams, turnover declines, the productivity of both older and younger workers increases, and performance improves when teams are engaged in creative or complex decision-making tasks.

AARP empowers people to choose how they live as they age. Working with employers, we can reject ageist stereotypes and allow people to continue to thrive in the workforce, no matter their age.

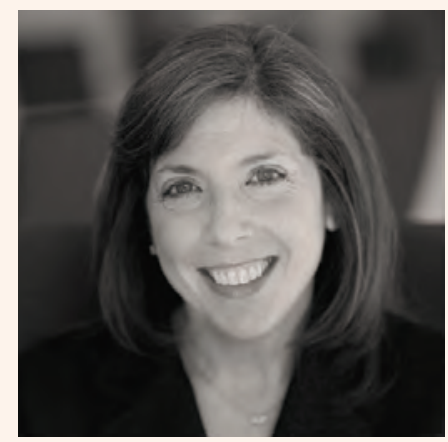

Susan Weinstock VICE PRESIDENT OF FINANCIAL RESILIENCE, AARP 